УДК 37.091.33-027.22:796

\title{
УПЕВНЕНІСТЬ У СОБІ ЯК УМОВА ПСИХІЧНОГО ЗДОРОВ'Я ЮНАКІВ НА УРОКАХ ФІЗИЧНОЇ КУЛЬТУРИ
}

Ірина Сундукова ${ }^{1}$

${ }^{1}$ Центральноукраїнський державний педагогічний університет імені В. Винниченка, м. Кропивницький, Україна, irinasyndykova@gmail.com

https://doi.org/10.29038/2220-7481-2019-01-71-76

\begin{abstract}
Анотаціï
Aктуальність. На основі теоретичного аналізу з'ясовано, що впевненість у собі впливає на психічне здоров'я учнів та їхне емоційне благополуччя. Упевненість у собі - це позитивне інтегроване ставлення до власних можливостей, що зумовлюється особливостями особистісного розвитку, становленням самосвідомості, подоланням залежності особистості від зовнішньої детермінації, узгодженням Я-реального та Я-ідеального. Натомість причиною формування невпевненості в собі й депресивних розладів особистості $є$ переважання процесів гальмування над процесами збудження, що призводить до формування «гальмівної особистості», не здатної до відкритого вираження своїх почуттів, бажань і потреб. Результати. Визначено такі характеристики психічно здорової й упевненої в собі особистості: відкритість, невербальне спілкування, віра у власні сили, спонтанне вираження почуттів, самоздійснення «тут і зараз». Систематичні заняття фізичною культурою спонукають учнів не лише до ведення здорового способу життя, а й розвивають здатність адекватно оцінювати можливості своєї особистості; формують упевненість у собі та своїх фізичних і моральних силах; сприяють умінню налагоджувати позитивний емоційний зв'язок у взаємодії з партнерами у фізкультурній діяльності; розвивають здатності управляти своїми переживаннями та негативними емоційними станими. Установлено, що більшість респондентів мають середній рівень упевненості в собі, що виявляється в помірному вираженні цілеспрямованості й наполегливості. Старшокласники цього рівня доволі зважено ставляться до визначення своїх цілей та засобів, якими мають намір досягати поставленої мети. Висновки. Зазначено, що в процесі занять фізичною культурою в учнів з'являються інтерес і звичка до систематичного виконання фізичних вправ, розвиваються морально-вольові якості: сміливість, наполегливість, дисциплінованість, взаємодопомога, упевненість у собі та своїх можливостях тощо.
\end{abstract}

Ключові слова: упевненість у собі, психічне здоров'я, фізична культура, самоставлення, емоційне благополуччя.

Ирина Сундукова. Уверенность в себе как условие психического здоровья юношей на уроках физической культуры. Актуальность. На основе теоретического анализа установлено, что уверенность в себе влияет на психическое здоровье учащихся и их эмоциональное благополучие. Уверенность в себе - это положительное интегрированное отношение к собственным возможностям, что обусловлено особенностями личностного развития, становлением самосознания, преодолением зависимости личности от внешней детерминации, согласованию Я-реального и Я-идеального. Зато причиной формирования неуверенности в себе и депрессивных расстройств личности является преобладание процессов торможения над процессами возбуждения, что приводит к формированию «тормозной личности», не способной к открытому выражению своих чувств, желаний и потребностей. Результаты. Определяются следующие характеристики психически здоровой и уверенной в себе личности: открытость, невербальное общение, вера в собственные силы, спонтанное выражение чувств, самореализации «здесь и сейчас». Систематические занятия физической культурой побуждают учеников не только к ведению здорового образа жизни, но и развивают способность адекватно оценивать возможности своей личности; формируют уверенность в себе и своих физических и моральных силах; способствуют умению налаживать позитивную эмоциональную связь во взаимодействии с партнерами в физкультурной деятельности; развивают способности управлять своими переживаниями и негативными эмоциональными состояниями. Установлено, что большинство респондентов имеют средний уровень уверенности в себе, что проявляется в умеренном выражении целеустремленности и настойчивости. Старшеклассники этого уровня достаточно взвешенно относятся к определению своих целей и средств, которыми намерены добиваться поставленной цели. Выводы. Отмечается, что в процессе занятий физической культурой у учащихся появляются интерес и привычка к систематическому выполнению физических упражнений, развиваются морально-волевые качества: смелость, настойчивость, дисциплинированность, взаимопомощь, уверенность в себе и своих возможностях и т. п.

Ключевые слова: уверенность в себе, психическое здоровье, физическая культура, самоотношение, эмоциональное благополучие.

Irina Sundukova. Self-Confidence as a Prerequisite for the Mental Health of Young Men in Physical Education Classes. Based on a theoretical analysis, it has been established that self-confidence affects the mental health of 
students and their emotional well-being. Self-confidence is a positive integrated attitude towards one's own capabilities, which is caused by the peculiarities of personal development, the formation of self-awareness, the overcoming of the dependence of the individual on external determination, the coordination of the I-real and I-ideal. Instead, the reason for the formation of self-doubt and depressive personality disorders is the predominance of inhibition processes over excitation processes, which leads to the formation of a «inhibitory personality», unable to openly express their feelings, desires and needs. The following characteristics of the mentally healthy and self-confident personality are defined: openness, nonverbal communication, faith in own forces, spontaneous expression of feelings, self-realization «here and now». Systematic physical education encourages students not only to maintain a healthy lifestyle, but also develop the ability to adequately assess the capabilities of their personality; form confidence in themselves and their physical and moral strengths; promote the ability to build a positive emotional connection in cooperation with partners in physical culture activities; develop the ability to manage their experiences and negative emotional states. It is established that the majority of respondents have an average level of self-confidence, which manifests itself in moderate expression of determination and perseverance. High school students of this level are quite balanced in defining their goals and the means with which they intend to achieve their goals. It is noted that in the process of physical education students have an interest and habit to systematically perform physical exercises, develop moral and volitional qualities: courage, perseverance, discipline, mutual assistance, self-confidence and their capabilities, and the like.

Key words: self-confidence, mental health, physical culture, self-attitude, emotional well-being.

Вступ. У сучасних умовах розвитку суспільства особливої уваги потребує проблема розвитку та формування фізично й психічно здорової особистості. Простежуємо невідповідність між значущістю фізичної культури й великим обсягом навчального навантаження на учнів, що призводить до систематичного накопичення втоми, що негативно позначається на емоційному стані та здоров”і школярів. Це викликає перенапругу психофізичних систем, зняти яку можливо завдяки систематичним заняттям фізичною культурою. Особливістю уроків фізичної культури є те, що в процесі їх проведення в учнів формуються та вдосконалюються рухові вміння й навички, розвиваються такі фізичні якості, як сила, швидкість, витривалість, спритність та гнучкість, що значно позначається на психічному розвиту зростаючої особистості.

У процесі занять фізичною культурою в учнів формується позитивне ставлення до свого здоров'я, 3'являються стійкий інтерес і звичка до систематичного виконання фізичних вправ, у процесі опанування фізичних навантажень розвиваються морально-вольові якості, а саме сміливість, наполегливість, дисциплінованість, взаємодопомога, упевненість у собі та своїх можливостях тощо.

Аналіз останніх джерел і публікацій. Теоретичний аналіз упевненості в собі, у яких феномен упевненості досліджується комплексно і як особистісна характеристика (Дж. Вольпе І. Кон, М. Левітов, В. Ромек, А. Сальтер), та розгляд специфіки впевненості в собі в юнацькому віці (Є. Кочнєва, М. Селіверстова, О. Федосенко). Теоретичні положення самоставлення досліджували О. В. Камінська, В. В. Століна, В. М. М'ясищев та ін. Незважаючи на різноманіття підходів до феномену «впевненість» як у вітчизняній, так і в зарубіжній психології впевненість у собі розглядають як рису особистості (Є.П. Щербаков); процес домінування збудження над процесами гальмування (А. Сальтер); психічний стан (М. Д. Левітов), самооцінку (О. О. Серебрякова). Сутність цього поняття полягає в тому, що впевненість у собі - це позитивне ставлення особистості до власних навичок, умінь, здібностей, можливостей і досягнень.

Мета дослідження - виявлення рівня впевненості в собі учнів старших класів на уроках фізичної культури.

Для досягнення мети дослідження використано такі методи та методики дослідження: теоретичний аналіз й узагальнення даних науково-методичної літератури, метод збору соціальної інформації (опитування), методи математичної статистики - $\varphi^{*}$ критерій кутового перетворення Фішера, порівняльний аналіз із наступною якісною інтерпретацією та змістовим узагальненням. Для виводу всіх даних дослідження в графічну форму (діаграми, гістограми) застосовано програму Excel for Windows (версія 2010).

Дослідницько-експериментальну роботу виконували на базі комунального закладу «НВО «Багатопрофільний ліцей - фізико-математична школа - загальноосвітня школа I-III ст. № 18 - Центр дитячої та юнацької творчості «Надія» м. Кропивницький. Загальна кількість старшокласників (учні 1011 класів), які брали участь в експерименті, становила 167 осіб. Метою опитувальника «Упевненість у собі» (Ф. Зімбардо) було визначення рівня цієї якості в старшокласників. Високий рівень характеризує внутрішнє відчуття сили, що проявляється за необхідності виконувати на уроках фізичної культури складні завдання. Середній рівень виявляється в адекватному співвідношенні своїх сил і складності 
поставленого завдання. Низький рівень пов'язаний із тим, що особистість за наявності відповідних фізичних даних, не вірить у власні можливості та здібності.

Результати дослідження. Як відомо, фізична культура є складовою частиною загальної культури суспільства, яка спрямовує особистість на формування та розвиток фізичних здібностей, на зміцнення здоров'я з метою поліпшення фізичного й духовного потенціалу особистості [10]. М. С. Корольчук розглядав фізичну культуру як базову для зміцнення здоров'я людини, торкався питання про те, яке місце займає здоров'я в системі цінностей особистості, які ідеали та установки вона обирає, намагаючись цілеспрямовано вплинути на свій фізичний стан. Здоров'я не може бути доведене до ідеалу й стати основною життєвою цінністю без практичних занять фізичною культурою чи спортом [3].

Систематичні заняття фізичною культурою впливають на усвідомлення юнаками своїх фізичних можливостей, досягнення фізичної досконалості, що виявляється в стрункій фігурі в дівчат та фізичній силі в хлопців.

А. Сальтер першим у психології почав досліджувати феномен упевненості в собі. Учений уважав, що причиною формування невпевненості в собі й депресивних розладів особистості $є$ переважання процесів гальмування над процесами збудження, що, на його думку, призводить до формування «гальмівної особистості», не спроможної до відкритого вираження своїх почуттів, бажань і потреб. Він виділив такі характеристики психічно здорової та впевненої в собі особистості, як відкритість, невербальне спілкування, віра у власні сили, спонтанне вираження почуттів, самоздійснення «тут і зараз» [7].

К. А. Абульханова-Славська вивчала впевненість у собі в контексті аналізу механізмів регуляції активності особистості. Незнаходження людиною адекватного зовнішнім завданням способу активності виявляється у двох крайнощах, як у заниженій ролі «Я», невпевненості в собі, так і в завищеній «Я», підтвердженні своєї винятковості. Згідно з поглядами вченої, невпевненість у собі є підставою для виокремлення різних типів активності, процесу саморегуляції, що опосередковує взаємозв'язок між домаганнями й досягненнями особистості [1, с. 3-18].

В. О. Сухомлинський вважав, що впевненість дитини формує в неї віру в себе: «Людина повинна навчитися бачити себе - i бачити правильно. Завдання ж дорослих - навчити дитину звітувати собі у своїх успіхах та невдачах» [11]. Лише успіх дитини формує в неї достатню віру в себе, а на цій основі упевненість у власних можливостях.

Як зазначав С. К. Мельничук, стабільне позитивне ставлення особистості до своїх здібностей, можливостей, умінь, навичок, досягнень становить основу її впевненості в собі [5]. В. Г. Ромек визначав упевненість особистості в собі як головну умову ії психічного здоров'я. Він пов'язував іiї із такими особливостями, як здатність людини реалізовувати свої плани, досягати поставлених цілей. Це викликає почуття задоволеності життям і самим собою. Такі переживання витісняють негативні емоції та позитивно впливають на ставлення людини до себе й навколишніх [8]. Серед деструктивних емоцій, які стоять на заваді досягненню впевненості в собі в юнацькому віці, Дж. Вольпе виокремлював тривожність. На думку вченого, «тривожність і невпевненість можна подолати, якщо страх у соціальній ситуації замінити іншою, не сумісною зі страхом емоцією або поведінкою» [16, с. 24-25]. Такими «замінниками» можуть бути емоції, що виникають під час спортивної гри (наприклад футболу чи волейболу), удалого виконання складних для старшокласників елементів спортивної гімнастики тощо.

Розвиток упевненості в собі зумовлюється особливостями особистісного та професійного самовизначення, становленням самосвідомості, подоланням залежності особистості від зовнішньої детермінації, узгодженням Я-реального і Я-ідеального й посиленням здатності до самодетермінації та саморозвитку [5].

В. Г. Ромек зазначав, що впевнена в собі людина відверто й без страху висловлює свої почуття, досягає поставленої мети, задоволена собою, відкрито говорить про власні бажання, не викликаючи негативних емоцій у ставленні до себе [8].

Згідно 3 поглядами Т. В. Шипелик, упевненість у собі, цілеспрямованість і наполегливість корелюють із почуттям відповідальності особистості за те, як вона реалізується в житті 14]. У зв'язку 3 цим А. О. Реан зазначав, що чим позитивніше уявлення особистості про себе, тим оптимістичнішим у неї стає ставлення до життя. Для неї має бути важливим сформувати, передусім, суб' єктне позитивне уявлення про себе [6]. Як зазначала Н. Я. Чиренко, ціннісне ставлення до себе є системним утворенням особистості, продуктом індивідуального розвитку людини, у чому виявляється активна суб'єктна спрямованість особистості. Вона належить до цінностей ії свідомості та поведінки [12].

За А. Лазарусом, упевнена людина повинна володіти здатністю відкрито говорити про свої бажання й вимоги; сказати «ні»; відкрито висловлюватися про свої позитивні та негативні почуття; 
установлювати контакти, починати й закінчувати розмову. Невпевненість у собі виникає як наслідок несформованості або дефективності хоча б однієї з цих здібностей [15].

У дослідженні I. В. Сундукової доведено, що уроки фізичної культури спонукають старшокласників до ведення здорового способу життя; розвивають здатність юнаків адекватно оцінювати можливості своєї особистості при співвіднесенні їх із поставленими завданнями; формують упевненість у собі та своїх фізичних і моральних силах; сприяють вмінню налагоджувати позитивний емоційний зв'язок у взаємодії з партнерами у фізкультурній діяльності; розвивають здатність у юнаків управляти своїми переживаннями, долаючи негативні емоційні стани [9].

Досліджуючи впевненість у собі, маємо підкреслити роль самоповаги юнака, яка передбачає задоволення собою, самоприйняття, позитивне самоставлення, узгодженність реального та ідеального «Я». У психологічних дослідженнях доведено, що старшокласники, які мають високий рівень самоповаги, вірять у себе й у те, що можуть подолати власні недоліки. Учні з низькою самоповагою переживають почуття неповноцінності, меншовартості. Це негативно позначається на емоційному самопочутті та психічному здоров'ї особистості. Ураховуючи погляди В. М. Чернокозової, бачимо, що зміст ціннісного самоставлення старшокласників полягає, насамперед, у їх самоповазі, у визнанні власної гідності; у розвитку індивідуальності, у визначенні свого місця в житті, у піклуванні про свій фізичний, розумовий та моральний розвиток [13].

Загалом позитивне самоставлення чинить вплив на емоційний комфорт юнаків. Воно корелює 3 оцінкою педагогів, батьків, ровесників, із рівнем навчальної успішності. В емпіричному дослідженні С. М. Лабінської встановлено, що розвитку позитивного самооцінювання особистості в цей період сприяють мотивація досягнення успіху, помірна здатність до ризику, низький показник особистісної тривожності та відсутність страхів, пов'язаних із ситуаціями контакту з учителями, батьками й однолітками, пізнавальний мотив навчальної діяльності, адекватний рівень домагань, упевненість у собі, самоповага [4]. На уроках фізичної культури активізуються вказані особливості, а саме культивується мотивація досягнення успіху (коли перед учнями ставлять завдання щодо виконання вправ чи досягнення певних результатів), виявляється бажання старшокласників ризикнути та підняти «планку» своїх фізичних можливостей, подолати зайве хвилювання й страх перед нездатністю впоратися з поставленими вчителем завданнями тощо.

Із викладеного вище можна визначити такі ознаки невпевненості в собі на уроках фізичної культури:

- пасивність на уроці фізичної культури;

- неадекватна реакція на зауваження вчителя;

- повне підпорядкування думці інших людей щодо себе та всього, що відбувається;

- небажання перебувати в центрі подій (змагань);

- страх відповісти відмовою на численні прохання однолітків;

- порівняння себе з іншими й формування заниженої самооцінки;

- постійна тривога, що переходить у стійкі неврози.

Дискусія. Із метою виявлення рівня впевненості юнаків у собі на уроках фізичної культури нами застосовано опитувальник «Упевненість у собі» (Ф. Зімбардо) [2].

Кількісні показники впевненості старшокласників у собі

Таблиия 1

$\mathrm{n}=167$

\begin{tabular}{|c|c|c|c|c|c|}
\hline \multirow{2}{*}{ Рівень упевненості в собі } & \multicolumn{2}{|c|}{10 клас $\mathrm{n}=75$} & \multicolumn{2}{|c|}{11 клас $n=92$} & \multirow{2}{*}{$\begin{array}{c}\text { Критерій } \varphi^{*} \\
\text { Фішера }\end{array}$} \\
\hline & аб.с. & $\%$ & абс. & $\%$ & \\
\hline Високий & 20 & 26,6 & 33 & 35,8 & $1,27 *$ \\
\hline Середній & 39 & 52 & 43 & 46,7 & $0,68^{*}$ \\
\hline Низький & 16 & 21,3 & 16 & 17,3 & $0,64 *$ \\
\hline Усього & 75 & 100,0 & 92 & 100,0 & \\
\hline
\end{tabular}

Умовне позначення: *- $\varphi^{*}$ емп $<\varphi^{*} к р$ 
Як видно з таблиці, в учнів старших класів домінує середній рівень упевненості в собі (52 \% школярі 10-х класів і 46,7 \% - 11-х). Він виявляється в помірному вираженні в досліджуваних цілеспрямованості та наполегливості. Старшокласники цього рівня доволі зважено ставляться до визначення своїх цілей і засобів, якими мають намір їх досягати. Зазвичай адекватно співвідносять свої сили та складність завдання, яке потрібно виконати. Загалом ці школярі позитивно себе сприймають, довіряють своїм можливостям, ціннісно ставляться до себе.

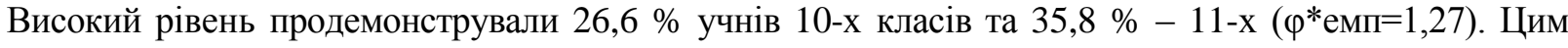
досліджуваним властиві такі риси, як наполегливість, цілеспрямованість, здатність брати на себе відповідальність за свої вчинки й результати діяльності. Вони готові самостійно приймати рішення, їх реалізовувати та організовувати інших у потрібних ситуаціях. Їм властиве внутрішнє відчуття власної сили, що проявляється за необхідності виконувати на уроках фізичної культури доволі складні завдання. Така віра у свою особистість зумовлена одночасно ознакою ціннісного ставлення до себе.

Низький рівень упевненості в собі продемонстрували 21,3\% учнів 10-х класів і 17,3 \% - 11-х. Невпевнені в собі юнаки відрізняються тим, що, ставлячи перед собою певні цілі, можуть відступати від означеного шляху, не виявляють наполегливості в подоланні зовнішніх і внутрішніх перешкод. Маючи хороші фізичні дані, школярі не вірять у те, що можуть їх реалізувати й проявити на уроках фізичної культури. У прийнятті відповідальних рішень $\epsilon$ боязкими. Не ризикуючи брати відповідальність за свої рішення, старшокласники цього рівня не готові також відповідати за інших. Закритість невпевнених у собі учнів 10-11-х класів не приносить їм психологічного благополуччя, а навпаки, створює негативне емоційне тло, на якому проблемним стає вирішення питання досягнення психічного здоров'я.

Висновки. Результати теоретичного аналізу та експериментального дослідження засвідчили, що впевненість у собі впливає на психічне здоров’я учнів і їхнє емоційне благополуччя. Упевненість у собі виявляється в позитивній самооцінці, у самоповазі та у визнанні власної гідності. Установлено, що більшість респондентів мають середній рівень упевненості в собі, що виявляється в помірному вираженні цілеспрямованості й наполегливості. Старшокласники цього рівня доволі зважено ставляться до визначення своїх цілей і засобів, якими мають намір досягати поставленої мети. Систематичні занятя фізичною культурою спонукають учнів не лише до ведення здорового способу життя, а й розвивають здатність адекватно оцінювати можливості своєї особистості; формують упевненість у собі та своїх фізичних і моральних силах; сприяють умінню налагоджувати позитивний емоційний зв'язок у взаємодії з партнерами у фізкультурній діяльності.

Подальші дослідження планується проводити в напрямі підвищення рівня впевненості учнів у собі й гармонійного розвитку особистості на уроках фізичної культури.

\section{Джерела та література}

1. Абульханова-Славская К. А. Типология активности личности Психологический журнал. 1985. Т. 6, № 5 . C. 3-18.

2. Зелінська Т. М. Михайлова І. М. Практикум із загальної психології: навч. посіб. Київ: Каравела, 2009. C. $110-112$.

3. Корольчук М. С. Крайнюк В. М., Косенко А. Ф., Кочергіна Т. І. Психологічне забезпечення психічного і фізичного здоров'я / за ред. М. С. Корольчука. Київ: Фірма «ІНКОС», 2002. 272 с.

4. Лабінська С. М. Психологічні чинники розвитку рівня домагань підлітків в учбовій діяльності: дис. ... канд. психол. наук: 19.00.07 «Педагогічна та вікова психологія»/Нац. держ. пед. ун-т ім. М. П. Драгоманова, Київ, 2016. 216 с.

5. Мельничук С. К. Сутність, структурні компоненти та критерії вивчення впевненості в собі. Вісник Інституту розвитку дитини. Вип. 21. Київ, 2012. С. 134-139.

6. Психология подростка: учебник/под ред. члена-корреспондента РАО А. А. Реана. Санкт-Петербург: ПРАЙМ-ЕВРОЗНАК, 2007. 480 c.

7. Ромек В. Г. Поведенческая психотерапия: учеб. пособие для студентов высш. учеб. заведений. Москва: Издат. центр «Академия», 2002. 192 с.

8. Ромек В. Г. Понятие уверенности в себе в современной социальной психологи. Психологический вестник РГУ. 1996. Вып. 1 (Ч. 2). С. 132-146.

9. Сундукова I. В. Формування ціннісного ставлення старшокласників до психічного здоров'я засобами фізичної культури: автореф. дис. ... канд. психол. наук: спец. 19.00.07 «Педагогічна та вікова психологія»/Нац. пед. ун-т ім. М. П. Драгоманова. Київ, 2018. 22 с.

10. Сутула В. О. Базові ознаки фізичної культури особистості. Духовність особистості: методологія, теорія і практика: зб. наук. праць СНУ ім. В. Даля. Луганськ, 2012. № 6 (53). С. 186-192. 
11. Сухомлинский В. А. Избранные произведения: в 5-ти т./ред. кол.: Дзеверин А. Г. и др. Киев: Рад. шк., 1979. T. 3. $301 \mathrm{c}$.

12. Чиренко Н. Я як цінність. Про формування ціннісного ставлення до себе. Шкільний світ. 2007. № 46. C. 6-8.

13. Чорнокозова В. М., Чорнокозов І. І. Бесіди на морально-етичні теми. Київ.: Рад. шк., 1976. 110 с.

14. Шипелик Т. В. Проблема становлення личностно смыслового уровня психического здоровья у подростков. Проблеми сучасної психології: зб. наук. праць Кам'янець-Подільського нац. ун-ту ім. Івана Огієнка, Ін-ту психології ім. Г. С. Костюка НАПН України/за ред. С. Д. Максименка, Л. А. Онуфрієвої. Вип. 20. Кам’янець-Подільський: Аксіома, 2013. С. 747-758.

15. Lazarus R. S., Folkman S. Stress, aprasial and coping. New York: Springer, 1984. 444 p.

16. Wolpe J., Jones T., Wear D., Lester D. Health Humanities Reader. Friedman Rutgers University Press, 2014. $448 \mathrm{p}$.

\section{References}

1. Abulhanova-Slavskaya, K.A. (1985). Tipologiya aktivnosti lichnosti [Typology of life-activity of personality]. Psihologicheskiy zhurnal. T. 6, no. 5, 3-18.

2. Zelinska, T. M. Mykhailova, I. M. (2009). Praktykum iz zahalnoi psykholohii [Workshop on General Psychology]. Navch.posibn. Kyiv: Karavela, $110-112$.

3. Korolchuk, M. S,. Krainiuk, V. M., Kosenko, A. F., Kocherhina, T. I. (2002). Psykholohichne zabezpechennia psykhichnoho i fizychnoho zdorovia [Psychological support for mental and physical health]. Kyiv: Firma «INKOS», 272.

4. Labinska, S. M. (2016). Psykholohichni chynnyky rozvytku rivnia domahan pidlitkiv v uchbovii diialnosti [Psychological factors in the development of the level of adolescent harassment in educational activities]. Dys. kand. psykhol. nauk: 19.00.07 «Pedahohichna ta vikova psykholohiia». Natsionalnyi derzh. pedahohichnyi un-t im. M. P. Drahomanova. Kyiv, 216.

5. Melnychuk, S. K. (2012). Sutnist, strukturni komponenty ta kryterii vyvchennia vpevnenosti v sobi [Essence, structural components and criteria for self-confidence study]. Visnyk Instytutu rozvytku dytyny. Kyiv, Vyp. 21, 134 139.

6. Psihologiya podrostka (2007) [Psychology of the adolescent]. Uchebnik/Pod red. A.A. Reana. SPb.: PRAYMEVROZNAK, 480.

7. Romek, V. G. (2002). Povedencheskaya psihoterapiya [Behavioral Psychotherapy].Ucheb. posobie dlya stud. vyissh. ucheb. zavedeniy. Moskva: Izdatelskiy tsentr«Akademiya», 192.

8. Romek, V. G. (1996). Ponyatie uverennosti v sebe v sovremennoy sotsialnoy psihologi [The concept of selfconfidence in modern social psychology]. Psihologicheskiy vestnik RGU. Vyp. 1 (Ch. 2), 132-146.

9. Sundukova, I. V. (2018). Formuvannia tsinnisnoho stavlennia starshoklasnykiv do psykhichnoho zdorovia zasobamy fizychnoi kultury [Formation of the value attitude of senior pupils to mental health by means of physical culture]. Avtoref. dys. na zdobuttia nauk. stupenia kand. psykhol. nauk: spets. 19.00 .07 «Pedahohichna ta vikova psykholohiia». Natsionalnyi pedahohichnyi un-t im. M. P. Drahomanova. Kyiv, 22.

10. Sutula, V. O. (2012). Bazovi oznaky fizychnoi kultury osobystosti. Dukhovnist osobystosti: metodolohiia, teoriia i praktyka [Basic signs of physical culture of personality. Spirituality of personality: methodology, theory and practice]. zb. nauk. pr. SNU im. V. Dalia, no. 6 (53), 186-192.

11. Suhomlinskiy, V. A. (1979). Izbrannyie proizvedeniya [Selected Works]. V 5-ti t./Red. kol.: Dzeverin A.G. i dr. Kiev.: Rad. Shkola. T. 3, 301.

12. Chyrenko, N. Ya. (2007). Ya yak tsinnist. Pro formuvannia tsinnisnoho stavlennia do sebe [I'm like a value. About formation of value attitude towards oneself]. Shkilnyi svit, no. 46, 6-8.

13. Chornokozova, V. M., Chornokozov, I. I. (1976). Besidy na moralno-etychni temy [Conversations on moral and ethical topics]. Kyiv: Radianska shkola,110.

14. Shipelik, T. V. (2013). Problema stanovlennya lichnostno smyislovogo urovnya psihicheskogo zdorovya u podrostkov [The problem of becoming a personally-minded level of mental health in adolescents]. Problemy suchasnoi psykholohii: Zbirnyk naukovykh prats Kamianets-Podilskoho natsionalnoho universytetu imeni Ivana Ohiienka, Instytutu psykholohii imeni H.S. Kostiuka NAPN Ukrainy/Za red. S. D. Maksymenka, L. A. Onufriievoi. Vyp. 20, Kamianets-Podilskyi: Aksioma, 747-758.

15. Lazarus, R.S., Folkman, S. (1984). Stress, appraisal and coping. New York: Springer, 444.

16. Wolpe, J., Jones, T., Wear, D., Lester, D. (2014). Health Humanities Reader. Friedman Rutgers University Press, 448.

Стаття надійшла до редакції 20.03.2019 р. 